\title{
Marc Brooks
}

University of Vienna, Austria

Univerza na Dunaju, Avstrija

\section{The Word is not Enough: Symbol, Myth, and Ritual in Hofmannsthal's Libretto for Arabella}

\section{Beseda ni dovolj: Simbol, mit in obrednost v Hofmannsthalovem libretu Arabella}

Prejeto: 1. januar 2013

Sprejeto: 27. marec 2013

Ključne besede: Richard Strauss, Hugo von Hofmannsthal, Arabella, Kunstreligion, obrednost

\section{IZVLEČEK}

Michael Steinberg trdi, da so opere Straussa in Hofmannsthala uspešne zato, ker je apoliničnost Hofmannsthalovih libretov uravnotežena z dinamičnostjo ali dionizičnostjo Straussove glasbe. Članek preizkuša to tezo z opazovanjem Hofmansthalovih metafizičnih spisov in njegove korespondence s Straussom.
Received: 1st January 2013

Accepted: 27th March 2013

Keywords: Richard Strauss, Hugo von Hofmannsthal, Arabella, art-religion, ritual

ABSTRACT

Michael Steinberg claims that the Strauss-Hofmannsthal operas are successful because Hofmannsthal's fixed, or 'Apollonian' libretto is counteracted by Strauss's dynamic, or 'Dionysian' music. This paper challenges this view by looking at Hofmannsthal's metaphysical writings and his correspondence with Strauss.

One common explanation for Hofmannsthal's desire to become a librettist is that he felt that words on their own were inadequate for aesthetic expression and he hoped that music would supply the transcendent sheen necessary for art-religious experience. His early symbolist poetry gestured towards the metaphysical, a literary version of the Wagnerian music that was supposed to bring the listener into contact with the Schopenhauerian Wille. The 'Letter of Lord Chandos' ('Ein Brief', 1902) was Hofmannsthal's admission of the impossibility - or even the undesirability - of this 'Dionysian' goal. ${ }^{1}$ However, in his 1927 address 'Literature as the Spiritual Space of the

1 The research for this paper was carried out with funding from the AHRC. I would like to thank Mark Berry, John Deathridge, Michael Fend, Roger Parker, and Nicholas Till for their helpful comments on earlier versions of the text, as well as Stephen Groves and Arabella Cizmas for looking over the final proofs. Any remaining errors are entirely the fault of the author.

Wagner's idea of a Dionysian music is explored at length in Nietzsche's Die Geburt der Tragödie aus dem Geiste der Musik (1872). 
Nation' ('Das Schrifttum als geistiger Raum der Nation', delivered 10 January 1927 at the University of Munich, published July 1927), written just before beginning work on Arabella (1933), his mature reflection was that 'literature [Schrifttum]' could indeed perform a spiritual function after all: not the Dionysian function of Wagnerian opera and his earlier symbolist poetry, in which unity is achieved by breaking down the division between individual souls, but instead achieving unity in the outer communal world through a shared language. ${ }^{2}$ Hofmannsthal here uses 'literature' not to mean just the pile of books that even the educated elite haven't yet found the time to absorb completely, but rather a 'spiritual activity' - constituted of all linguistic utterance - that lies beside, outside, beneath, and above professional literature which could serve as the 'spiritual room' in which the German-speaking nation would be formed. Language is not inadequate for the spiritual dimension of existence; language is all there is.

The function of the artist is to become a Nietzschean 'seeker' - a term borrowed from the Untimely Meditations (Unzeitgemässe Betrachtungen, 1876) - who is able internalize all the contradictions of the culture in order to present a unified outer reality that can serve as the mythological basis for the nation. Michael Steinberg has argued that there is nothing Nietzschean about Hofmannsthal's attempt to imagine a fixed, eternal mythology for the Germans because Nietzsche had a more 'Dionysian' view of culture as 'historical and dynamic'. ${ }^{3}$ For Steinberg, the Hofmannsthal-Strauss collaborations (particularly Arabella) are successful because Strauss's avowedly Nietzschean music - basing 'his compositional style on the principle of Dionysian movement' - cuts across Hofmannsthal's attempts to present a static ideology. This itself is debateable, but the purpose of this paper is to challenge the specific idea that Hofmannsthal's libretto is Apollonian in opposition to Strauss's Dionysian music - i.e. that the opera functions in essentially the same way as its Wagnerian precedents. In Wagner's metaphysical conception, music is aligned with a higher reality and is thus able to communicate the deeper universal truth that lies behind the words. Music allows a glimpse of the infinite when the listener compares the unlimited multiplicity of possible myths contained in the musical Ur-myth with the specificity of the single myth enacted on the stage and in the words. In opposition to this 'inner Dionysian' aesthetic, in which aesthetic unity is experienced internally by the individual as the music subsumes them in the Wille, I argue that Hofmannsthal was aiming for an 'outer Dionysian' aesthetic in Arabella, in which unity is transferred into the external experience of the shared linguistic space. This is done through allegorical symbolism, the invention of mythical worlds that obscure contradictions, and the enactment of both of these through time in ritual.

\section{Word}

After his precocious success as a teenage poet, Hofmannsthal reached a crisis point early in his career when he realized that language had become so colonized by scien-

2 Hugo von Hofmannsthal, Gesammelte Werke in Einzelausgaben, ed. Herbert Steiner, vol. 14: Prosa IV (Frankfurt am Main: S. Fischer Verlag, 1955).

3 Hofmannsthal borrowed this interpretation from Ernst Bertram's Nietzsche: Versuch einer Mythologie (1918): Michael P. Steinberg, The Meaning of the Salzburg Festival (Ithaca, NY: Cornell University Press, 1990), 161 
tific thought and means-end rationality that even the temporary, artificial respite afforded by symbolist poetry was no longer possible. This 'Sprachkrise', already evident in Hofmannsthal's early poetry and lyric dramas, found its clearest expression in the much discussed 'Letter of Lord Chandos' ('Ein Brief', 1902). The fictional letter concerns the ontological status of language, and asks to what extent it is able to express or represent certain real human experiences like the sense of Self or the feeling of belonging to a Higher Order. Neither the letter's date, 1603, nor its addressee, Francis Bacon, are coincidental. The date is right in the middle of the Scientific Revolution. ${ }^{4}$ And Bacon is often credited with the invention of the 'scientific method' - what he called the 'novum organum' - in which knowledge is determined through inductive reasoning based on empirical observation. ${ }^{5}$ By addressing the letter to Bacon, then, Hofmannsthal was indicating that the root of the language crisis was the separation of scientific and symbolic thought bequeathed by him and his contemporaries.

The fictional author of 'Ein Brief' is tormented by the absurdity that, although he feels the integrity of his inner self deeply, he knows that any attempt to express it in words is doomed. Hofmannsthal's way of escaping this condition was to invent a pared-down metaphysic that incorporated positivist thinking - even the prohibition on metaphysics - in order to turn it into a virtue. The soul is no longer the Cartesian 'ghost in the machine', to borrow Gilbert Ryle's phrase, but consists of the separation between that part of us that observes and the part we observe: 'the soul is inexhaustible because it is at once both observer and object ${ }^{6}{ }^{6}$ The attempt to achieve Dionysian unity, to transcend the infinite and finite parts of our nature, would only bring chaos in which nothing is distinguishable. ${ }^{7}$ Instead, although plurality is the cause of all suffering (Schopenhauer's principium individuationis), we should not see it as something to be transcended, but the source of the " "magic" in our nature'. 'Self-transcendence' is achieved, paradoxically, by accepting that it is our essential non-transcendence that makes us who we are: we overcome ourselves by learning that we do not need to overcome our divided selves.? The consequence of this distinctly Nietzschean embrace of reality and suffering is that striving for the infinite in art becomes a betrayal of the equally important finite part of our being. But on the other hand, attempting a synthesis between finite and infinite would look like a misguided attempt to overcome our defining plurality. So the only choice left to the artist is an unconditional affirmation of reality.

Hofmannsthal's letters to Strauss about Arabella demonstrate what this abstract philosophizing meant in practice. Hofmannsthal tried to create a believable Spielwelt in

4 I date the Scientific Revolution - a contentious term in current historiography - between the publication dates of Copernicus's De revolutionibus orbium coelestium (1543) and Newton's Philosophice Naturalis Principia Mathematica (1687) respectively.

5 'Men have sought to make a world from their own conception and to draw from their own minds all the material which they employed, but if, instead of doing so, they had consulted experience and observation, they would have the facts and not opinions to reason about, and might have ultimately arrived at the knowledge of the laws which govern the material world'. Francis Bacon, The New Organum, ed. Lisa Jardine \& Michael Silverthorne (Cambridge: Cambridge University Press, 2000).

6 Hugo von Hofmannsthal, Gesammelte Werke in Einzelausgaben, ed. Herbert Steiner, vol. 11: Prosa I, (Frankfurt am Main: S. Fischer Verlag, 1956), 8.

7 Benjamin Bennett, Hugo Hofmannsthal: The Theatres of Consciousness (Cambridge: Cambridge University Press, 1988), 12-3. His argument is based on a close reading of Hofmannsthal's early notes.

8 Ibid., 11.

9 Ibid., 15-6 
which a workable 'configuration [Gestalt]' of characters is assembled. ${ }^{10}$ The archetypal model he had in mind for Arabella was Die Meistersinger von Nürnberg (1868) to which Der Rosenkavalier (1911) owed so much. He believed that the Nuremberg of the $1830 \mathrm{~s}$ that Wagner had contact with 'offered not merely a mirror, but actually an example of the whole intellectual and spiritual life of the German middle class around 1500'. ${ }^{11}$ The implication is that, having been born in 1874 , he was close to having had direct experience of the world he is trying to recreate in Arabella. The horror with which he reacted to Strauss's suggestion for a 'colossal Croatian ballet' in the second act shows his commitment to verisimilitude. '[It] is exactly the decisive point that everything must be authentic, the authentic Vienna of 1860s, just as Der Rosenkavalier owes some part of its success to the fact that it remains true to the authentic Vienna of 1740 throughout'. ${ }^{2}$ It is not discussed in the correspondence, but this attitude extended to set and costume design, which he ensured were faithful to the period in question. ${ }^{13}$ There seems, then, to have been a complete rejection of the lyricism of the earlier poetry: everything is geared towards a mimetic, albeit highly stylized, recreation of a real world.

Nevertheless, the opera is very far from being realistic. This not just because of the apparently trivial point that sung theatre cannot be perceived as real. The lyric-affective mode which depicts the characters' internal emotional states is no less realistic than other forms of theatrical or cinematic realism. Hofmannsthal was keen that the music be as understated as possible, with the singers leading and the orchestra in a subordinate role. Strauss obliged and further contributed to the sense of realism by having the vocal line follow the natural speech patterns of the language. ${ }^{14}$ The problem with the term 'realism' comes from Hofmannsthal's use of dialogue and staging to externalize the consequences of the metaphysical system outlined above.

One way he does this is encapsulated by his well-known dictum: 'Depth must be hidden. Where? On the surface'. ${ }^{15}$ This is followed in Arabella by keeping the atmosphere so light that what are actually deep philosophical points sparkle in the conversations as mere witticisms. Another is summed up in another aphorism, which seems to contradict the encomia to authenticity in the letters: 'Naturalism distorts Nature because by copying the surface it has to neglect the wealth of inner relatedness - Nature's real mysterium'. ${ }^{16}$ This inner relatedness is conveyed through symbol, myth and the rituals that reinforce them. Everything in the libretto has symbolic meaning - the characters, their actions, their positioning on stage, the props they handle and what they talk about. Hofmannsthal might have been affirming the real, or the finite, in Arabella, but it does not mark a return to naturalism.

10 Hofmannsthal to Strauss, 22 December 1927, Richard Strauss and Hugo von Hofmannsthal, Correspondence, trans. Hanns Hammelmann and Ewald Osers (London: Collins, 1961), 461.

11 Hofmannsthal to Strauss, 1 July 1927 , Correspondence, 433.

12 Hofmannsthal, 22 December 1927, Correspondence, 463. Translation amended for clarity.

13 Reproductions of the designs for the original sets and costumes can be found in Kenneth Birkin, Arabella (Cambridge: Cambridge University Press, 1989).

14 See Hofmannsthal to Strauss, 26 July 1928, Correspondence, 495.

15 Hofmannsthal, "From "The Book of Friends"”, Selected Prose, trans. Mary Hottinger, Tania \& James Stern (New York: Pantheon, 1952), 362 .

16 Ibid., 374 . 


$\begin{array}{llllllllll}\text { M. BROOKS } & \text { THE } & \text { WORD } & \text { I S NOT } & \text { ENOUGH } & \ldots\end{array}$

\section{Symbol}

The dominance of Baconian scientific thought meant that the modern person was unable to apprehend the world without dichotomizing it into symbolic and rational thought, or another equivalent binary pair. ${ }^{17}$ The non-modern would make no distinction between 'religious' and 'scientific' thought; religious symbolism itself was functional, and few would have even considered whether its supposed effect was empirically verifiable. ${ }^{18}$ Artistic symbolism recreated a dim echo of this religious experience by using elliptical, melodic language in order to obscure the meaning of the symbols and evoke a dreamlike psychological state. But, however successful an individual artist was at evoking this état d'âme as an affect, the pretension that it allowed one to understand the inner meaning of things could only ever be seen as fakery. ${ }^{19}$ Arabella marked the culmination of a new way of thinking about the symbol in art for Hofmannsthal: it now functioned allegorically so that, although it could not be read with the precision of a linguistic signifier, each symbol opened up a loosely circumscribed space of meaning. This meant that, instead of the obscurity of a symbolism that attempted to fake the mystery of religious experience, the more legible symbols demonstrated how the 'encounter' enabled the individual to move away from the internal, infinite part of his being into the shared external, finite part of existence.

One of the most important recurring symbols in Hofmannsthal's oeuvre is that of 'outer [außen]' as opposed to 'inner [innen]'. Throughout the whole of the first act, the image of Arabella's going out is foremost. In the scene with Zdenka, she keeps looking out of the window towards the world with all its diverse possibilities. In the final solo scene she is preparing to go out in the present moment with Elemer, but she is also mentally preparing herself to go out to the ball that evening. These literal examples of 'going out' stand for the process of individuation: in order for the Self to come into existence it is necessary for it to undertake a figurative 'going out' into the world. ${ }^{20}$ The Self sits at the centre of the whole universe, as Chandos realizes in his moments of clarity: 'I, in a state of continuous intoxication, conceived the whole of existence as one great unit [...] thus it prevailed through the whole expanse of life in all directions; everywhere I was in the centre of it, never suspecting mere appearance'. ${ }^{21}$ According to Hofmannsthal's metaphysics, the World, which can only be one of appearance, is contained within the individual, and the Self and World can only become separate by attempting to act in the world. Through action, the person experiences resistance to his will which then serves to define the boundaries of the Self: 'living, or living oneself out

17 This tendency is demonstrated, for example, in the essay 'Concerning Two Kinds of Thinking' in Carl Jung, Psychology of the Unconscious: A Study of the Transformations and Symbolisms of the Libido, trans. Beatrice M. Hinkle (New York: Dodd, Mead \& Company, 1916), which Hofmannsthal had in his library.

18 Ladislav Holy, Religion and Custom in a Muslim Society: The Berti of Sudan (Cambridge: Cambridge University Press, 1991), 210.

19 This is the substance of the argument in Nietzsche's Der Fall Wagner (1888).

20 Draußen (the space outside the home) is acting as a metaphor for außen (the space outside herself in which she interacts with others).

21 Hugo von Hofmannsthal, "The Letter of Lord Chandos", The Whole Difference: Selected Writings of Hugo von Hofmannsthal, trans. Tania and James Stern (Princeton: Princeton University Press, 2008), 69-79; 72. 
MUZIKOLOŠKI ZBORNIK • MUSICOLOGICAL ANNUAL L/2

completely, [is possible] only in the struggle with opposing powers'. ${ }^{22}$

In his survey of the symbols of 'outer' and 'inner' in Hofmannsthal's output, J.H. Reid writes: 'all Hofmannsthal's heroes have to break out of their introverted state'. ${ }^{23}$ In Ariadne auf Naxos (1912/16), in a nod to the Wagnerian/early-Nietzschean stance of The Birth of Tragedy, going out of oneself means towards a Dionysian oneness with the universe. Ariadne hides in her cave, ignoring the advances of the commedia dell'arte troupe, who evoke the satyr chorus of Greek theatre, only emerging to embrace Bacchus who transforms her into a constellation of stars. In a step closer to what happens in Arabella, the Kaiserin in Die Frau ohne Schatten (1918) has her nonpersonhood symbolized by her lack of shadow; she is only able to gain selfhood by acting, or rather by deliberately not acting. It is her cry of 'Ich - will - nicht!', marking her refusal to drink from the fountain of life, which would deny the Dyer and his wife children, that enables her to join the world of life and gain a shadow. Arabella's 'cave' or 'lack of shadow' is her passivity, her peering out from behind the curtain and hoping that the world will come to her. As in the earlier operas, she only joins Life through her action at the very end.

There is, however, something that lifts Arabella above the solipsistic moaning of Ariadne or the mendacious thievery of the Kaiserin, and that is her awareness of the inherent potentiality of her situation. Arabella's most attractive qualities - knowing her own mind, being in control of her situation, and a willingness to take risks - do not square with her decision to sacrifice her own self-interest for that of her wastrel parents by marrying a rich count. ${ }^{24}$ The odd combination of headstrongness and passivity, in which she knows exactly what she wants but just sits around waiting for it to happen, can make her character seem aloof and unreasonable. But Hofmannsthal chose these attributes in order that she is best able to perform her symbolic function. When she does eventually 'go out' she does not feel constrained to do so within the parameters that have been set for her, but is prepared to look beyond the limits of her Viennese sphere. This is where the idea of the 'encounter', which Hofmannsthal first explored in a short prose work of 1907 , becomes important. The encounter offers the individual the opportunity for 'disintegration' and then a choice of the infinite possibilities available for 'reintegration':25 'At no moment is the sensual so close to the spiritual, the spiritual so sensual, as in the encounter. At this moment everything is possible, everything in flux, everything diffused'. ${ }^{26}$

For Hofmannsthal, it was people with Arabella's almost impossible mix of personality traits that were particularly susceptible to the power of the encounter: "For a very daring, very naïve imagination, [...] wherein innocence and cynicism are inextricably entangled, the encounter is already the anticipation of embrace'. ${ }^{27}$ Compare this to his

22 Hugo Hofmannsthal, Gesammelte Werke in Einzelausgaben, ed. Herbert Steiner, vol. 15: Aufzeichnungen, (Frankfurt am Main: S. Fischer Verlag, 1959), 127.

23 J. H. Reid, “"Draussen sind wir zu finden” - The Development of a Hofmannsthal Symbol”, German Life and Letters vol. 17, no. 1 (Fall 1973): 43.

24 For the genesis of these characteristics see Hofmannsthal's letters to Strauss, 20 November, 22 December, 25 December 1927 , Correspondence, $456,460,465$

25 Hofmannsthal, "Book of Friends", 353.

26 Hofmannsthal, "Encounters" (1907), Selected Prose, 208-9

27 Ibid., 209. 


$\begin{array}{lllllllll}\text { M. BROOKS } & \text { THE } & \text { WORD } & \text { IS } & \text { NOT } & \text { ENOUGH } & \ldots\end{array}$

description of Arabella to Strauss as 'a mature and beautiful girl who has probed too deeply into certain aspects of life, a little seared by cynicism and resignation'. ${ }^{28}$ Arabella admits that if her encounter were to result in an actual meeting, it is more than likely that 'he would become like anyone else to her', the spell would be broken just as it was with the other suitors. But while it remains just an encounter, she can derive that exquisitely mournful pleasure in contemplating the possible outcomes of a deeply desired meeting that will never happen. The purpose of the rest of the opera is to show how, when the encounter takes place in the right mythical framework and with the right attitude to ritual, that sense of possibility can be extended indefinitely into the future.

\section{Myth}

For the primitive, myth is a not a system of thought through which the world can be explained, it simply presents the world the way it is. The modern, conversely, is able to distinguish between those beliefs that are scientifically demonstrable, 'facts', and those that stem from religion or other types of superstition, 'myths'. 'Myth' in the sense Hofmannsthal would have understood the term, therefore, is a concept only available to moderns. This causes two interrelated problems: firstly, unlike myth, which sets out a basis for morality, science offers no criteria for making judgements; secondly, despite the fact myth has no scientific claim to truth, it seems to be indispensable for life. ${ }^{29}$ Following on from Nietzsche's treatment of this problem in Beyond Good and Evil (Jenseits Gut und Böse, 1886), Hofmannsthal wasn't concerned about the truth of his mythopoeic creations in some non-existent 'reality'; his task was to channel what is already available in the culture into something 'life-promoting'. ${ }^{30}$ The particular myth Hofmannsthal tapped into in Arabella was that of the Austro-Hungarian Empire, namely that Austria was uniquely able, through its shared cultural memory, to act as a lynchpin in Europe, tying Slav and Germanic countries together in supra-national harmony. ${ }^{31}$

On casual acquaintance with Arabella, one could be forgiven for assuming that Mandryka was the stock 'funny foreigner', who in Austrian theatre was traditionally a Slav (Prince Orlofsky in Die Fledermaus is a good example). However, in Hofmannsthal's post-war stage works the Slav started to serve a more serious purpose. ${ }^{32}$ In Der Schwierige (1921), he was primarily concerned with unfavourably contrasting modern German character types with the already mythical pre-war Austrian aristocrat. The Slavs only appear in absentia, but Hofmannsthal emphasized their willingness to join with their Austrian fighting comrades on the Carpathian front in defence of the Empire. Like Arabella, Der Unbestechliche (1923) has a Slav as a main character, a butler

28 Hofmannsthal to Strauss, 25 December 1927, Correspondence, 465.

29 Bronislaw Malinowski, an anthropologist who did his important fieldwork in the 1920s, called it a 'vital ingredient of human civilization': Magic, Science and Religion, and Other Essays (Garden City, NY: Doubleday Anchor, 1948 ), 101.

30 Nietzsche, Beyond Good and Evil, Basic Writings of Nietzsche (2000), 201-2.

31 See Hofmannsthal, "Antwort auf die Umfrage "Svenska Dagbladet"” [1915] (Übersetzt von Friedrich Stieve), Gesammelte Werke, Aufzeichnungen, 363 and Hofmannstahl to Bodenhausen, 10 July 1917, Briefe der Freundschaft (Düsseldorf E. Diederichs, 1953), 235-236.

32 J. B. Bednall, "The Slav Symbol in Hofmannsthal's Post-War Comedies", German Life and Letters vol. 14, no. 1-2 (1961): 36. 
Theodor, who acts as a foil to an Austrian society 'already gravely weakened by moral leukaemia'. ${ }^{33}$ Despite the comic mileage wrought from Theodor's mangled diction, his main function is as a symbol of volkish innocence, brought in to act as a guilty conscience for the main character, a young Baron.

This idea of the Slav as offering potential salvation to the morally corrupt Viennese was carried to its logical conclusion in Arabella, where Mandryka is of equal or greater social status than any of the Viennese, and it is he who gets the girl. In order to achieve this reversal Hofmannsthal conflated two ideals: that of the Austro-Hungarian Empire, with its connotations of strength through diversity, and that of the Volk. The still relatively large mass of peasants, around one third of the population of Austria at the time, were seen by the Conservative Revolutionaries as part of any remedy for society's ills, since they were uncontaminated by the mistakes of the nineteenth century or any of the intellectual problems posed by modernity. Mandryka retains the SlavGerman idiom from his army days, but his delivery is more nuanced than Theodor's: Hofmannsthal 'provides him with constructions and figures of speech which blend convincingly with his Slav imagery'. ${ }^{34}$ And it is this imagery, of the autochthonous Slav with the 'aura of tall, silent forests, of deep, spontaneous emotion, of self-sufficiency and an uncorrupted natural order', through which Hofmannsthal is able to sell the volkish ideal to his audience. ${ }^{35}$

Hofmannsthal's saw the Conservative Revolution in terms of centuries and he was under no illusion that an immediate retreat from modernity was possible. By staging the mythical ideal of Bodenständigkeit - the sense of identity with folk, soil and immediate homeland, unchanging values, and oneness with ancestors and past - through the Slav symbol, he had the more modest aim of drawing out qualities that were already latent in the modern audience. What we have in Arabella, then, is the mirror image of what Edward Said saw occurring in much nineteenth century literature, where the orient is concocted as a mysterious other through which the darker regions of the European psyche might be explored. ${ }^{36}$ Hofmannsthal's positively marked, but equally fictive, other - knitted together from a nostalgia for empire, a Romantic deification of nature and a city-dweller's ignorance of the realities of feudal life - would, he believed, resonate sufficiently with audiences to encourage them to shake off their spiritual torpor. For this to work, the portrait of Vienna he painted had to be allegorically recognizable as the contemporary city and, for all their faults, the characters had to seem severely misguided rather than rotten to the core.

Hofmannsthal achieved this by ensuring all the characters other than Arabella and Mandryka were caricatures, each exhibiting one amusing trait. Hofmannsthal described the three Counts as in 'frivolous pursuit of all skirts' and Waldner as 'that cashiered cavalry captain and his whole shady milieu' and how 'these figures are tainted by vulgarity, tangled up with a rather vulgar and dubious Vienna'. ${ }^{37}$ But the characters are not simply

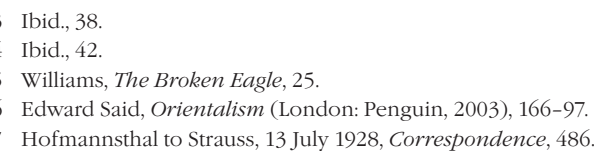


'vulgar', each is the victim of a crippling self-delusion: the Countess puts her faith in the prognostications of a fortune teller, the Count believes the answer to his financial problems lies at the gaming table, and the three young counts swim through life entitled to everything, striving for nothing. The biggest self-defeating fantasy of all, however, is that monetary wealth alone is necessary for deliverance. Waldner's gambling is shorthand for stock market speculation, and the alacrity with which he accepts Mandryka's money shows the morally bankrupt ethos of money for nothing prevalent during boom times as true in the 1920s, when the libretto was written, as it was in the 1860s, when it was set.

The point of the Slav mythology, then, was not to provide a scientifically verifiable theory of origins to replace the belief requirement of Christianity, but a utopian idea, whose fictiveness was always acknowledged, through which the present evils would be made manifest and a better way of organizing society imagined.

\section{Ritual}

Hofmannsthal's antipathy towards the Comtean revolution in the social sciences, in which all knowledge had to be purged of anything metaphysical or mysterious, was not without rational foundation. ${ }^{38}$ In her book Ritual Theory, Ritual Practice, Catherine Bell shows how Hofmannsthal's anthropologist contemporaries, like Émile Durkheim, Arnold van Gennep and Rudolf Otto, who were involved in the positivization of theology, ended up trapped in the thought-action dichotomy through which 'ritual' is defined. ${ }^{39}$ In order to theorize ritual, the anthropologist separates its psychological component, which are called 'beliefs', from the bodily action, which is then termed 'ritual'. This then sets up a chain of consequent dichotomies. The first is the distinction between the scientist's analytical thought and the subject's symbolic thought, and since the former allows the scientist to 'understand' the latter, it unavoidably privileges that type of thinking. This then leads to the further separation of nature and supernature, or of sacred and profane, which might be viewed by insiders as continua.

The ritual process has typically been seen by the anthropologist as a process in which thought and action are dialectically synthesized. Ritual thereby reverses what only ever was a theoretical distinction in the first place, imposed from the outside and having nothing to do with the way it is seen by the participants. However, with the ubiquity of the scientific mode of thinking in intellectual discourse, it is impossible not to split religious practice, or art in its role as a humanist replacement for religion, into the evidentially effective and ineffective, or propositionally true and untrue. The well-known 'Staircase Scene', the finale of Arabella, represents Hofmannsthal's attempt to invent a way of performing ritual in which the truth or effectiveness of the ideas involved became unimportant.

Arabella and Mandryka do not simply enact a pre-existing ritual and thus confirm a set of firmly held religious beliefs. Instead they take two separate ritual practices from

38 William R. Everdell, "Chapter 2: The Century Ends in Vienna", The First Moderns (Chicago \& London: Chicago University Press, 1997), 13-29.

39 Catherine Bell, Ritual Theory, Ritual Practice (Oxford: Oxford University Press, 1992). 
their own cultures and combine them in an improvised manner. When Arabella hands the glass of water to Mandryka, which he then takes, empties and then smashes against the stairs, the couple are explicitly acting out the local betrothal rite that he told her about when he proposed in Act II. The glass of water that the bride-to-be would draw from the river, then pass to her suitor, has a number of associations. It represents virginal purity, as Arabella acknowledges when she hands over the glass with the words: 'and so I present this untouched drink to my friend'. It also represents fidelity, which is reinforced by Mandryka smashing the glass against the steps so that "no one will ever drink out of this glass after me'. Further, water is often thought of as a source of life and when it occurs with the feminine can be a symbol of fertility. And it also stands for the cycle of life and death: the death of the girl Arabella and her rebirth into womanhood.

Before handing over the glass to Mandryka, Arabella sings of a 'power ... from above [Macht ... von oben]', referring to the transformative, purifying power of Mandryka's love.

But after, when I felt you here standing in the dark,

A great power from above touched my heart,

So that I no longer had to refresh myself with a drink,

No, a feeling of happiness had already refreshed me [...]

[Dann aber, wie ich Sie gespürt hab' hier im Finstern stehn,

hat eine grosse Macht mich angerührt von oben bis ans Herz,

dass ich mich nicht erfrischen muss mit einem Trunk:

nein, mich erfrischt schon das Gefühl von meinem Glück, [...] ]

In giving him the water that she wanted for herself, she is making a sacrifice for Mandryka. In the Catholic tradition, Lent is a period of self-denial and abstinence which the believer undergoes in order to purify himself before the festival of Easter, when Jesus's sacrifice is celebrated. At the start of this process, on Ash Wednesday, the penitent must confess and ask for forgiveness from a priest. In this scene, which almost certainly takes place in the early hours of Ash Wednesday, Arabella is acting like a priest and, instead of painting the sacramental cross of ashes on his forehead, gives Mandryka the glass of water as a symbol of absolution. Although the secularity of the ritual is never in doubt (Hofmannsthal only uses the verb 'verzeihen', never 'vergeben', which is used in religious expressions such as 'vergeben der Sünden', 'the remission of sins'), what initially appears to be the Slav betrothal rite can just as easily be seen as an echo of the Catholic absolution rite.

Earlier accounts of the libretto have tended to masculinize the opera - something Carolyn Abbate has noticed at play in the discourse on Elektra (1909) - painting Mandryka as a 'redeemer' come to rescue Arabella from the clutches of a depraved city. ${ }^{40}$ It is certainly true Mandryka is the 'key' to the whole work - a point Hofmannsthal flattered Strauss for understanding - and that the glass of water is meant to resonate with the Slav symbol Mandryka as a sign of spiritual purity. ${ }^{41}$ But although Mandryka is a welcome 'breath of fresh totally different air' come to blow the filth of corruption

40 J. B. Bednall does this in "The Slav Symbol in Hofmannsthal's Post-War Comedies", German Life and Letters vol. 14, no. 1-2 (1961): 42 .

41 Hofmannsthal to Strauss, 13 July 28, Correspondence, 486-7. 
away from the city', the purification does not travel in only one direction; Vienna has something to give in return, its unique ability to form bonds with, and draw strength from, foreign cultures. The result is a mutual transformation, which Arabella accomplishes by appropriating an alien ritual from her suitor and combining it with her own indigenous practice. The scientifically unprovable belief systems that are articulated by either Slavic (pagan) or Catholic ritual are secondary to the performative nature of the action which brings together two culturally different individuals regardless of any symbolic/mythical meaning. It carries the necessary weight of tradition(s), which supplies the necessary spiritual feeling to the occasion, but without the need for supernatural intervention or the sanction of a fixed dogma.

\section{POVZETEK}

Hofmannsthalovo odločitev, da postane libretist, se običajno utemeljuje z njegovim prepričanjem, da besede ne zadostujejo za estetski (umetnostnoreligiozni) izraz. Upal naj bi, da bo glasba dala njegovim besedilom transcendentalni blesk, potreben za doseganje umetnostno-religioznega doživetja. Namen pričujočega besedila je kritično oceniti tezo, da je Hofmannsthalov libreto za opero Arabella (1933) apoliničen, Straussova glasba pa dionizična - t. j. da je v tem pogledu podobna svojim wagnerjanskim predhodnicam. V Wagnerjevi metafizični zasnovi je glasba povezana z višjo stvarnostjo, skozi katero lahko sporoča globljo univerzalno resnico, ki leži za besedami. Glasba omogoča vpogled v neskončnost, ko poslušalec primerja neomejeno mnoštvo možnih mitov, vsebovanih v pra-mitu, z določnostjo mita, uresničenega na odru in $\mathrm{v}$ besedilu. V nasprotju s to "notranje dionizično" estetiko, v kateri estetsko enovitost notranje doživlja posameznik, ko ga glasba poveže z Wille, trdim, da si je Hofmannsthal v Arabelli prizadeval za "zunanje dionizično" estetiko, v kateri se povezanost uresničuje v skupnem zunanjem lingvističnem prostoru. To dosega $z$ alegoričnim simbolizmom in ustvarjanjem mitičnih svetov, ki prikrijejo protislovja, ter uresničevanjem obeh v času s pomočjo obrednosti.

Prevod naslova, izvlečka in povzetka Aleš Nagode 


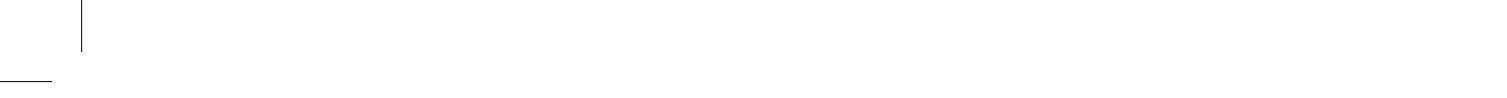

